\title{
Studi Literatur Mikroenkapsulasi Bakteri Asam Laktat sebagai Bahan Aktif Sediaan Cokelat untuk Anti-Diare pada Anak
}

\author{
Adelya Pratiwi",Dina Mulyanti \\ Universitas Islam Bandung, Indonesia. \\ *adelyapratiwi04@gmail.com, dina.sukma83@gmail.com
}

Prodi Farmasi, Fakultas Matematika dan Ilmu Pengetahuan Alam,

\begin{abstract}
Lactobacillus plantarum and Lactobacillus acidophilus are included in lactic acid bacteria (BAL) which are probiotic bacteria that have health benefits in humans. The viability of both BAL can be decreased during the product manufacturing process, storage, and when passing through the gastrointestinal tract. Microencapsulation can be used to solve the problem. This literature study aims to study methods and coating materials that are more suitable for microenkapsulation of $\mathrm{L}$. plantarum and $\mathrm{L}$. acidophilus therefore can made as an active ingredient in chocolate. This literature study used data sources research from indexed national and internatioanl journals as the method. The results of this study showed that the use of freeze drying method resulted in a smaller decrease in BAL viability than spray drying. The use of maltodextrin and skimmed milk can reduce the viability of both BAL. The combination of the both coating materials can increase the thermoprotective effect, therefor BAL will be heat resistant.
\end{abstract}

Keywords: Microencapsulation, L. plantarum, L. acidophilus, Spray Drying, Freeze Drying, Maltodextrin, Skim Milk.

\begin{abstract}
Abstrak. Lactobacillus plantarum dan Lactobacillus acidophilus termasuk ke dalam bakteri asam laktat (BAL) yang merupakan bakteri probiotik yang memiliki manfaat kesehatan pada manusia. Viabilitas dari kedua BAL tersebut dapat mengalami penurunan selama proses pembuatan produk, penyimpanan, dan saat melewati saluran cerna. Pembuatan mikroenkapsulasi dapat digunakan untuk mengatasi masalah tersebut. Studi literatur ini bertujuan untuk mengkaji metode dan bahan penyalut yang lebih sesuai untuk mikroenkapsulasi L. plantarum dan L. acidophilus agar dapat menjadi bahan aktif pada sediaan cokelat. Metode yang digunakan pada penelitian ini yaitu studi literatur dengan menelaah sumber dari berbagai jurnal internasional maupun jurnal nasional yang terindeks. Hasil penelitian ini menunjukkan bahwa penggunaan metode freeze drying menghasilkan penurunan viabilitas BAL yang lebih kecil daripada spray drying. Penggunaan bahan penyalut maltodekstrin dan susu skim dapat memperkecil penurunan viabilitas kedua BAL. Penggabungan kedua bahan penyalut tersebut dapat meningkatkan efek termoprotektif, sehingga BAL akan lebih tahan panas.
\end{abstract}

Kata Kunci: Mikroenkapsulasi, L. plantarum, L. acidophilus, Spray Drying, Freeze Drying, Maltodekstrin, Susu Skim. 


\section{A. Pendahuluan}

Bakteri Asam Laktat (BAL) merupakan mikroflora normal yang terdapat di dalam saluran pencernaan manusia dan juga merupakan probiotik terpenting yang diketahui memiliki efek menguntungkan pada saluran pencernaan manusia (Burgain et al., 2011). Probiotik didefinisikan sebagai mikroorganisme hidup yang dapat memberikan manfaat kesehatan pada inangnya apabila diberikan dalam jumlah yang memadai (Hill et al., 2014). BAL yang umumnya digunakan sebagai probiotik yaitu Lactobacillus dan Bifidobacterium spp. (Giraffa, 2012). Selain itu, bakteri probiotik juga merupakan alternatif yang potensial dalam pencegahan dan pengendalian infeksi yang ditularkan melalui makanan, karena diketahui efektif dalam menghambat patogenisitas patogen penyebab infeksi (Campana, Van Hemert and Baffone, 2017).

Efek menguntungkan BAL pada saluran pencernaan manusia diantaranya adalah dapat mengatasi dan mencegah diare, mengatasi intoleransi laktosa, mencegah terjadinya tukak lambung, dan mengatasi maag (Masood et al., 2011). Sejumlah penelitian yang telah dilakukan terhadap anak-anak, BAL menunjukkan manfaat pada infeksi saluran cerna akut dan antibiotic associated diarrhea (AAD) (Agustina, 2012).

Penyakit diare akut masih menjadi salah satu penyebab utama morbiditas dan mortalitas pada anak usia di bawah 5 tahun di Indonesia, dengan angka kematian 2,3 per 1000 anak (Indriyani, Juffrie and Setyati, 2012). BAL yang umum digunakan sebagai probiotik untuk mengobati diare diantaranya adalah Lactobacillus plantarum (Yan and Goldman, 2020) dan Lactobacillus acidophilus (El-Soud et al., 2015).

BAL biasanya ditambahkan ke dalam berbagai produk makanan dan minuman agar dapat dikonsumsi dengan mudah (Wong, Odamaki and Xiao, 2019), salah satunya yaitu cokelat (Mirković et al., 2018). Diketahui bahwa viabilitas BAL dalam sediaan pangan dapat mengalami penurunan selama proses pembuatan produk, penyimpanan (Pradipta, 2017), dan saat dikonsumsi (berada dalam sistem pencernaan) (Adib et al., 2013). Oleh karena itu, upaya peningkatan viabilitas BAL harus dilakukan, salah satu caranya adalah dengan teknik mikroenkapsulasi (Solanki et al., 2013).

Teknik mikroenkapsulasi dapat dilakukan dengan penambahan bahan penyalut yang umumnya digunakan untuk menyalut probiotik, yaitu susu skim dan maltodekstrin (Nocianitri, Sujaya and Ramona, 2019). Susu skim digunakan sebagai salah satu bahan penyalut karena mengandung kasein yang memiliki efek melindungi bahan inti. Kasein sangat stabil dengan adanya suhu tinggi dan tidak menyebabkan koagulasi akibat dari pemanasan pada suhu $100{ }^{\circ} \mathrm{C}$ selama 24 jam atau pemanasan pada suhu $140{ }^{\circ} \mathrm{C}$ selama 20 menit (Yudiastuti et al., 2019). Sedangkan maltodekstrin dianggap bahan penyalut yang baik karena memiliki viskositas yang rendah, kelarutan yang tinggi, dan daya ikat yang tinggi dalam membentuk mikrokapsul (Balasubramani et al., 2015), harganya relatif murah, lebih komersil, dan mudah didapat (Nocianitri, Sujaya and Ramona, 2019).

Metode mikroenkapsulasi yang umumnya digunakan untuk mengenkapsulasi probiotik yaitu ekstrusi, spray drying (Solanki et al., 2013), dan freeze drying (de Vos et al., 2010). Teknik spray drying merupakan proses pendispersian bahan inti di dalam bahan penyalut, yang diikuti dengan atomisasi dan penyemprotan campuran tersebut ke dalam chamber pengering dengan udara panas. Sedangkan teknik freeze drying merupakan proses penjerapan yang terjadi berdasarkan proses liofilisasi pada larutan emulsi yang mengandung bahan inti dan bahan penyalut (Suganya and Anuradha, 2017).

Berdasarkan uraian di atas, maka rumusan masalah dari studi literatur ini adalah menganalisa metode serta bahan penyalut yang paling sesuai untuk enkapsulasi BAL jenis $L$. plantarum dan $L$. acidophilus agar memiliki viabilitas yang baik di 
dalam sediaan cokelat. Maka dari itu, penelitian ini bertujuan untuk mengetahui metode dan bahan penyalut yang lebih sesuai untuk enkapsulasi $L$. plantarum dan $L$. acidophilus agar dapat menjadi bahan aktif pada sediaan cokelat. Studi literatur ini diharapkan dapat memberikan informasi ilmiah terkait mikroenkapsulasi L. plantarum dan L. acidophilus yang ditambahkan ke dalam formula cokelat.

\section{B. Metodologi Penelitian}

Metode yang digunakan pada penelitin ini yaitu menggunakan studi literatur dengan mencari berbagai sumber berupa jurnal internasional, junrla nasional dan buku yang didapat secara daring. Pencarian sumber tersebut dilakukan melalui Garuda, Google Scholar, PubMed, ScienceDirect, Springer, Taylor \& Francis, dan Wiley dengan kata kunci "Lactic acid bacteria", "Encapsulation", Microencapsulation of lactic acis bacteria".

Kemudia dilakukan pemilihan jurnal berdasarkan kriteria inklusi dan kriteria eksklusi.

Berikut kriteria inklusi:

1. Jurnal yang terbit 10 tahun terakhir (2011-2021)

2. Jurnal yang berbentuk penelitian.

3. Jurnal tentang enkapsulasi L. plantarum dengan bahan penyalut maltodekstrin dan/atau susu skim menggunakan metode spray drying dan/atau freeze drying.

4. Jurnal tentang enkapsulasi L. acidophilus dengan bahan penyalut maltodekstrin dan/atau susu skim menggunakan metode spray drying dan/atau freeze drying. Dan berikut kriteria eksklusi:

1. Jurnal yang terbit lebih dari 10 tahun terakhir (sebelum 2011)

2. Jurnal yang berbentuk review

3. Jurnal tentang enkapsulasi tetapi bukan bakteri L. plantarum dan L. acidophilus

4. Jurnal tentang enkapsulasi L. plantarum dan L. acidophilus tetapi bukan dengan bahan penyalut maltodekstrin dan/atau susu skim serta bukan menggunakan metode spray drying dan/atau freeze drying.

Selanjutnya dilakukan ekstraksi data dan kemudian data tersebut dianalisis hingga didapat data yang sesuai untuk menjawab rumusan masalah dan tuujuan penelitian yang telah ditentukan.

\section{Hasil Penelitian dan Pembahasan}

\section{Viabilitas BAL setelah Proses Mikroenkapsulasi}

Viabilitas L. plantarum dan L. acidophilus dalam bentuk sel bebas (tanpa bahan penyalut) mengalami penurunan yang lebih besar dibandingkan sel bakteri dengan bahan penyalut setelah dilakukan proses mikroenkapsulasi dengan metode spray drying dan freeze drying. Hal tersebut dapat dilihat pada Tabel 1.

Penurunan viabilitas kedua BAL tersebut dapat terjadi karena adanya pengeringan yang menggunakan suhu tinggi pada proses spray drying dan adanya pembekuan yang menggunakan suhu rendah pada proses freeze drying (Lapsiri, Bhandari and Wanchaitanawong, 2013; Sohail et al., 2013; Maciel et al., 2014; Soukoulis et al., 2014; Wang et al., 2016, 2019; Reyes et al., 2018; Tang et al., 2020). Diketahui bahwa kedua BAL tersebut memiliki kemampuan tumbuh maksimal pada suhu $45{ }^{\circ} \mathrm{C}$ dan minimal pada suhu 15 ${ }^{\circ} \mathrm{C}$ (Todorov and de Melo Franco, 2010; Bull et al., 2013), sehingga pada saat proses enkapsulasi L. acidophilus dan L. plantarum menjadi tidak stabil. Maka dari itu, untuk menjaga agar bakteri tetap stabil dapat dilakukan dengan penambahan matriks atau bahan penyalut (Poddar et al., 2014). 
Tabel 1. Penurunan Viabilitas L. plantarum dan L. acidophilus

\begin{tabular}{|c|c|c|c|}
\hline Bahan Penyalut & Metode & Penurunan Viabilitas & Pustaka \\
\hline \multicolumn{4}{|c|}{ Lactobacillus plantarum } \\
\hline $\begin{array}{l}\text { 1. } \mathrm{MD} \\
\text { 2. } \mathrm{P} \\
\text { 3. } \mathrm{T} \\
\text { 4. } \mathrm{F} \\
\text { 5. GA }\end{array}$ & $\begin{array}{l}\text { Spray drying dengan } \\
\text { suhu inlet } 120^{\circ} \mathrm{C} \text { dan } \\
\text { suhu outlet } 60^{\circ} \mathrm{C}\end{array}$ & $\begin{array}{c}\text { Tidak disebutkan } \\
\text { penurunan viabilitasnya }\end{array}$ & $\begin{array}{c}\text { (Lapsiri, Bhandari } \\
\text { and } \\
\text { Wanchaitanawon } \\
\text { g, 2013) }\end{array}$ \\
\hline $\begin{array}{l}\text { 1. } \mathrm{MD} \\
\text { 2. GA }\end{array}$ & $\begin{array}{l}\text { Spray drying dengan } \\
\text { suhu inlet } 140^{\circ} \mathrm{C}\end{array}$ & $\begin{array}{l}\text { 1. Setelah spray drying } \\
\text { MD: } 1,16 \log \mathrm{CFU} / \mathrm{g} \\
\text { GA: } 0,17 \log \mathrm{CFU} / \mathrm{g} \\
\text { 2. Pada suhu } 4{ }^{\circ} \mathrm{C} \text { selama } \\
60 \text { hari } \\
\text { a. Vakum } 97 \% \text { : } \\
\text { MD: } 0,24 \log \mathrm{CFU} / \mathrm{g} \\
\text { GA: } 0,95 \log \mathrm{CFU} / \mathrm{g} \\
\text { b. Vakum } 10 \% \text { : } \\
\text { MD: } 0,75 \log \mathrm{CFU} / \mathrm{g} \\
\mathrm{GA}: 1,04 \log \mathrm{CFU} / \mathrm{g}\end{array}$ & $\begin{array}{l}\text { (Reyes et al., } \\
\text { 2018) }\end{array}$ \\
\hline $\begin{array}{l}\text { 1. NA } \\
\text { 2. SM } \\
\text { 3. I }\end{array}$ & $\begin{array}{c}\text { Freeze drying dengan } \\
\text { suhu }-70^{\circ} \mathrm{C} \text { selama } 24 \\
\text { jam }\end{array}$ & $\begin{array}{l}\text { Sel bebas setelah freeze } \\
\text { drying : } 1,47 \log \mathrm{CFU} / \mathrm{mL}\end{array}$ & $\begin{array}{l}\text { (Wang et al., } \\
\text { 2016) }\end{array}$ \\
\hline & Lacto & acidophilus & \\
\hline
\end{tabular}

\begin{tabular}{|c|c|c|c|}
\hline $\begin{array}{l}\text { 1. SM } \\
\text { 2. SW }\end{array}$ & $\begin{array}{l}\text { Spray drying dengan } \\
\text { suhu inlet } 180^{\circ} \mathrm{C} \text { dan } \\
\text { suhu outlet } 85-95^{\circ} \mathrm{C}\end{array}$ & $\begin{array}{c}\text { Tidak disebutkan } \\
\text { penurunan viabilitasnya }\end{array}$ & $\begin{array}{l}\text { (Maciel et al., } \\
\text { 2014) }\end{array}$ \\
\hline $\begin{array}{l}\text { 1. NA } \\
\text { 2. MD }\end{array}$ & $\begin{array}{c}\text { Spray drying dengan } \\
\text { suhu inlet } 120^{\circ} \mathrm{C} \text { dan } \\
\text { suhu outlet } 60^{\circ} \mathrm{C} \text { dan } \\
\text { freeze drying dengan } \\
\text { suhu }-80^{\circ} \mathrm{C} \text { selama } 48 \\
\text { jam }\end{array}$ & $\begin{array}{l}\text { 1. Setelah spray drying } \\
\text { MD: } 1,87 \log \mathrm{CFU} / \mathrm{g} \\
\mathrm{MD}+\mathrm{NA}: 2,25 \log \mathrm{CFU} / \mathrm{g} \\
\text { 2. Setelah freeze drying } \\
\mathrm{MD}: 1,59 \log \mathrm{CFU} / \mathrm{g} \\
\mathrm{MD}+\mathrm{NA}: 1,89 \log \mathrm{CFU} / \mathrm{g}\end{array}$ & $\begin{array}{c}\text { (Sohail et al., } \\
\text { 2013) }\end{array}$ \\
\hline
\end{tabular}

\begin{tabular}{|c|c|c|c|}
\hline $\begin{array}{l}\text { 1. } \mathrm{SM} \\
\text { 2. } \mathrm{S} \\
\text { 3. } \mathrm{MD} \\
\text { 4. } \mathrm{PJ}\end{array}$ & $\begin{array}{c}\text { Spray drying dengan } \\
\text { suhu inlet } 130^{\circ} \mathrm{C} \text { dan } \\
\text { suhu outlet } 70^{\circ} \mathrm{C} \text { dan } \\
\text { freeze drying dengan } \\
\text { suhu }-51^{\circ} \mathrm{C} \text { selama } 24 \\
\text { jam }\end{array}$ & $\begin{array}{l}\text { Sel bebas setelah: } \\
\text { 1. Spray drying: } 9,71 \\
\log \mathrm{CFU} / \mathrm{mL} \\
\text { 2. Freeze drying : } 4,12 \\
\log \mathrm{CFU} / \mathrm{mL}\end{array}$ & $\begin{array}{l}\text { (Tang et al., } \\
\text { 2020) }\end{array}$ \\
\hline 1. $\mathrm{MD}$ & & & \\
\hline $\begin{array}{l}\text { 2. SM } \\
\text { 3. PW } \\
\text { 4. NK } \\
\text { 5. G } \\
\text { 6. T } \\
\end{array}$ & $\begin{array}{c}\text { Spray drying dengan } \\
\text { suhu inlet } 134 \pm 1{ }^{\circ} \mathrm{C} \\
\text { dan suhu outlet } 76 \pm 1 \\
{ }^{\circ} \mathrm{C}\end{array}$ & $\begin{array}{c}\text { Tidak disebutkan } \\
\text { penurunan viabilitasnya }\end{array}$ & $\begin{array}{c}\text { (Soukoulis et al., } \\
\text { 2014) }\end{array}$ \\
\hline $\begin{array}{l}\text { 1. } \mathrm{MD} \\
\text { 2. } \mathrm{GA}\end{array}$ & $\begin{array}{l}\text { Spray drying dengan } \\
\text { suhu inlet } 150^{\circ} \mathrm{C} \text { dan } \\
\text { suhu outlet } 55 \pm 2{ }^{\circ} \mathrm{C}\end{array}$ & $\begin{array}{c}\text { Tidak disebutkan } \\
\text { penurunan viabilitasnya }\end{array}$ & $\begin{array}{c}\text { (Arepally, Reddy } \\
\text { and Goswami, } \\
\text { 2020) }\end{array}$ \\
\hline $\begin{array}{l}\text { 1. MD } \\
\text { 2. PW } \\
\text { 3. PWP }\end{array}$ & $\begin{array}{c}\text { Freeze drying dengan } \\
\text { suhu }-18^{\circ} \mathrm{C}\end{array}$ & $\begin{array}{c}\text { Tidak disebutkan } \\
\text { penurunan viabilitasnya }\end{array}$ & $\begin{array}{l}\text { (Wang et al., } \\
\text { 2019) }\end{array}$ \\
\hline
\end{tabular}

\section{Pengaruh Metode Mikroenkapsulasi terhadap BAL}

Spray drying dan freeze drying dapat mempengaruhi viabilitas dan stabilitas probiotik BAL (Sohail et al., 2013). Pada proses spray drying, inaktivasi sel diakibatkan oleh adanya suhu tinggi yang dapat mempengaruhi membran sitoplasma, dinding sel, DNA dan RNA bakteri, sehingga aktivitas metabolisme bakteri akan berkurang. Selain itu, dapat menyebabkan 
peningkatan permeabilitas sel yang akan mengakibatkan hilangnya komponen intraseluler dari dalam sel menuju ke luar sel (lingkungan ekstraselular) (Poddar et al., 2014; Tripathi and Giri, 2014).

Pada metode freeze drying, terdapat proses pembekuan dan pengeringan yang dapat menyebabkan inaktivasi sel bakteri. Sebagian besar, inaktivasi selular terjadi pada proses pembekuan dengan terbentuknya kristal es ekstraseluler, sehingga dapat menyebabkan kerusakan pada membran sel dan juga memberikan kondisi stres dengan osmolaritas yang tinggi (Tripathi and Giri, 2014; Iaconelli et al., 2015). Selain itu, pada proses pengeringan dapat terjadi kerusakan pada protein permukaan, dinding sel, dan membran sel akibat dari dehidrasi sel bakteri, serta dimungkinkan terjadi peroksidasi lipid (Tripathi and Giri, 2014).

\section{Bahan Penyalut yang Sesuai untuk BAL}

Maltodekstrin dan susu skim adalah bahan penyalut yang biasa digunakan untuk menyalut probiotik (Nocianitri, Sujaya and Ramona, 2019) yang diketahui dapat menghambat penurunan viabilitas BAL. Viabilitas BAL dengan bahan penyalut maltodekstrin menurun sebesar 1,87 log CFU/g setelah spray drying dan 1,59 log CFU/g setelah freeze drying (Sohail et al., 2013), sedangkan viabilitas BAL dengan bahan penyalut susu skim rata-rata menurun sebesar 3,72 $\log \mathrm{CFU} / \mathrm{mL}$ setelah spray drying dan 2,74 log CFU/mL setelah freeze drying (Tang et al., 2020).

Tabel 2 dan 3 menunjukkan bahwa selama penyimpanan 30 hari pada suhu $40{ }^{\circ} \mathrm{C}$, viabilitas BAL yang dienkapsulasi dengan bahan penyalut maltodekstrin atau susu skim mengalami penurunan viabilitas yang lebih besar dibandingkan dengan penyimpanan pada suhu 4 dan $25{ }^{\circ} \mathrm{C}$, baik itu mikroenkapsulasi BAL hasil spray drying maupun freeze drying (Tang et al., 2020). Hal tersebut dapat terjadi karena suhu penyimpanan yang rendah dapat memperlambat terjadinya reaksi merugikan dari mikroorganisme, seperti menghambat oksidasi lipid membran plasma yang dibentuk oleh fosfolipid tak jenuh, sedangkan suhu penyimpanan yang tinggi menyebabkan laju degradasi yang lebih tinggi (Wang et al., 2019).

Tabel 2. Penurunan Viabilitas BAL yang dienkapsulasi dengan Maltodekstrin selama penyimpanan 30 hari

\begin{tabular}{|c|c|c|c|c|}
\hline \multirow{2}{*}{ Metode } & \multirow{2}{*}{$\begin{array}{c}\text { Bahan } \\
\text { Penyalut }\end{array}$} & \multicolumn{3}{|c|}{ Penurunan Viabilitas } \\
\hline & & Suhu $4^{\circ} \mathrm{C}$ & Suhu $25^{\circ} \mathrm{C}$ & Suhu $40^{\circ} \mathrm{C}$ \\
\hline Spray drying & Maltodekstrin & $4,01 \log \mathrm{CFU} / \mathrm{mL}$ & $4,37 \log \mathrm{CFU} / \mathrm{mL}$ & $5,33 \log \mathrm{CFU} / \mathrm{mL}$ \\
\hline Freeze drying & & 3,48 $\log \mathrm{CFU} / \mathrm{mL}$ & 3,93 log CFU/mL & $4,46 \log \mathrm{CFU} / \mathrm{mL}$ \\
\hline
\end{tabular}

Maltodekstrin adalah bahan penyalut karbohidrat yang paling umum untuk enkapsulasi probiotik (Sanchez et al., 2013), yang dapat bermanfaat untuk menggantikan air dengan ikatan hidrogen pada gugus fosfolipid membran sel bakteri, dapat membentuk amorf selama pengeringan dan memberikan viskositas yang tinggi, sehingga dapat membatasi pertukaran air dan oksigen (Poddar et al., 2014). Selain itu, maltodekstrin merupakan polisakarida dengan berat molekul tinggi yang dihasilkan oleh pati yang umum digunakan untuk menjaga stabilitas mikrokapsul dan melindunginya terhadap perubahan fisik yang tidak diinginkan seperti lengket dan hancur, melindungi dari perubahan kimia seperti mencegah oksidasi bahan yang dienkapsulasi, dan selama pengeringan maltodekstrin (Sanchez et al., 2013; Reyes et al., 2018).

Susu skim adalah bahan penyalut protein yang umum digunakan dan mengandung dua jenis protein, yaitu kasein dan protein whey. Susu skim memiliki manfaat dalam mencegah kerusakan sel dengan menstabilkan membran sitoplasma, memfasilitasi rehidrasi sediaan kering, dapat membentuk lapisan pelingdung pada dinding sel untuk melindungi sel BAL (Halim et al., 2017). Kasein yang terkandung dalam susu skim yang tercerna di lambung dapat melepaskan peptida dan asam amino yang dapat mendukung pertumbuhan probiotik, serta protein whey dalam susu skim tidak terhidrolisis oleh cairan lambung sehingga dapat memberikan perlindungan (Maciel et al., 2014). Sedangkan protein whey dapat melepaskan asam amino yang mengandung belerang ketika adanya suhu panas, dimana belerang tersebut 
dapat mengikat oksigen sehingga menghambat oksidasi lipid (Soukoulis et al., 2014).

Kombinasi antara susu skim dan maltodekstrin dapat memberikan viabilitas yang lebih tinggi setelah proses enkapsulasi (Tang et al., 2020), karena penambahan maltodekstrin dapat meningkatkan efek termoprotektif dari susu skim, serta telah terbukti penggunaan maltodekstrin dan susu skim menjadi strategi yang baik untuk produksi enkapsulasi probiotik (Soukoulis et al., 2014). Selain dapat dikombinasi dengan maltodekstrin, susu skim juga dapat dikombinasikan dengan karbohidrat lain yaitu pektin. Menurut penelitian Yasmin et al., (2019), penggunaan pektin bersama dengan protein whey dapat meningkatkan efisiensi dan kebulatan bubuk hasil enkapsulasi, selain itu pektin dapat membentuk struktur seperti film yang berkontribusi terhadap peningkatan viabilitas sel dalam kondisi asam dan garam empedu. Telah diketahui bahwa susu skim sendiri mengandung protein whey (Lin et al., 2021).

Selain itu, pektin biasa digunakan sebagai bahan penyalut pada mikroenkapsulasi karena sifatnya yang resisten terhadap enzim pencernaan seperti amilase dan protease, serta tetap dalam bentuk agrerat makromolekul saat dalam media asam (Meneguin et al., 2017) sehingga dapat memberikan perlindungan pada BAL saat melewati saluran cerna. Pektin merupakan serat makanan sehingga dapat berperan sebagai prebiotik (Ginting, Antara and Wijaya, 2020) yang bermanfaat dalam menstimulasi satu atau lebih kelompok mikroba yang bermanfaat dalam usus, sehingga memiliki efek positif pada kesehatan manusia (Sarao and Arora, 2017).

Salah satu tanaman yang mengandung pektin sebagai kandungan utamanya yaitu cincau hijau (Ginting, Antara and Wijaya, 2020). Karena kandungan pektinnya cincau hijau juga telah digunakan sebagai bahan baku pembuatan edible coating (Hendrawan, Sumarlan and Ilham, 2017). Penelitian Winarsih (2018), menyatakan bahwa edible coating dengan bahan dasar cincau dapat memperpanjang masa simpan stroberi hingga 14 hari pada penyimpanan $5{ }^{\circ} \mathrm{C}$.

\section{BAL Terenkapsulasi dalam Sediaan Cokelat}

Cokelat merupakan pembawa yang lebih baik daripada susu untuk penghantaran oral probiotik (Posseimers, 2010), karena pembawa susu memiliki kerugian untuk orang yang memiliki alergi protein susu dan intoleransi laktosa, serta memerlukan pendinganan dan memiliki umur simpan yang relatif lebih singkat (Nambiar, Sellamuthu and Perumal, 2018). Selain itu, cokelat diketahui mengandung padatan kakao yang tinggi dikenal sebagai sumber polifenol, seperti katekin, prosianidin, proantosianin, dan flavonol glikosida. Adanya kandungan polifenol yang berperan sebagai antioksidan membuat cokelat bermanfaat menjadi pembawa untuk probiotik (Laličić-Petronijević et al., 2017). Cokelat juga merupakan makanan yang disukai oleh anak-anak, sehingga cokelat berpotensi sebagai pembawa BAL yang dienkapsulasi (Mirković et al., 2018; Nambiar, Sellamuthu and Perumal, 2018) untuk tujuan mengatasi masalah diare pada anak.

Berikut formula cokelat yang dapat digunakan sebagai pembawa BAL terenkapsulasi C (Nambiar, Sellamuthu and Perumal, 2018):

1. Padatan kakao $28 \%$

2. Sukrosa $4 \%$

3. Susu skim $16 \%$

4. Mentega kakao $15 \%$

5. Lesitin kedelai $00,3 \%$

BAL yang dienkapsulasi menggunakan maltodekstrin berhasil ditambahkan ke dalam formula cokelat tersebut dengan menghasilkan viabilitas BAL lebih besar dari 8 log CFU/g selama 180 hari pada suhu $25^{\circ} \mathrm{C}$ (Nambiar, Sellamuthu and Perumal, 2018).

\section{Kesimpulan}

Berdasarkan pembahasan dalam penelitian ini, peneliti menyimpulkan beberapa hasil penelitian sebagai berikut:

1. Metode mikroenkapsulasi yang lebih sesuai untuk L. plantarum dan L. acidophilus agar dapat ditambahkan pada formula cokelat yaitu freeze drying.

2. Bahan penyalut yang lebih sesuai untuk mengenkapsulasi $L$. plantarum dan $L$. 
acidophilus agar dapat ditambahkan ke dalam formula cokelat yaitu kombinasi antara maltodekstrin dan susu skim, dimana maltodekstrin dapat meningkatkan efek termoprotektid dari susu skim.

\section{Acknowledge}

Penulis sangat berterimakasih kepada semua orang yang telah memberi dukungan selama penulis menempuh pendidikan Farmasi di Universitas Islam Bandung, terutama kepada orang tua penulis yang tiada henti mendo'akan untuk kelancaran penulis. Selain itu, penulis berterimakasih kepada dosen pembimbing yaitu Ibu Dr. apt. Dina Mulyanti, M.Si. dan Ibu apt. Bertha Rusdi, M.Si., P.hD. yang telah memberi bimbingan sehingga penulis dapat menyelesaikan tugas akhir dengan tepat waktu.

\section{Daftar Pustaka}

[1] Adib, A. et al. (2013) 'Lactobacillus Plantarum Pada Feses Individu Dewasa Sehat Yang Mengonsumsi Lactobacillus Plantarum Is-10506 Dari Dadih', Jurnal Teknologi dan Industri Pangan, 24(2), pp. 154-161. doi: 10.6066/jtip.2013.24.2.154.

[2] Agustina, R. (2012) Effect of milk calcium with or without probiotics on growth, iron and zinc status of Indonesian children, Probiotics, calcium and acute diarrhea. Netherlands: Wageningen University. Available at: http://library.wur.nl/WebQuery/edepot/231281\#page=64.

[3] Bull, M. et al. (2013) 'The life history of Lactobacillus acidophilus as a probiotic: A tale of revisionary taxonomy, misidentification and commercial success', FEMS Microbiology Letters, 349(2), pp. 77-87. doi: 10.1111/1574-6968.12293.

[4] Burgain, J. et al. (2011) 'Encapsulation of probiotic living cells: From laboratory scale to industrial applications', Journal of Food Engineering, 104(4), pp. 467-483. doi: 10.1016/j.jfoodeng.2010.12.031.

[5] El-Soud, N. H. A. et al. (2015) 'Bifidobacterium lactis in treatment of children with acute diarrhea. A randomized double blind controlled trial', Macedonian Journal of Medical Sciences, 3(3), pp. 403-407. doi: 10.3889/oamjms.2015.088.

[6] Ginting, F. E., Antara, N. S. and Wijaya, I. M. M. (2020) 'Potensi Ekstrak Cincau Hijau (Premna oblongifolia Merr.) dalam Menstimulasi Pertumbuhan Bakteri Asam Laktat Saluran Pencernaan', Jurnal Rekayasa Dan Manajemen Agroindustri, 8(3), p. 319. doi: 10.24843/jrma.2020.v08.i03.p01.

[7] Giraffa, G. (2012) 'Selection and design of lactic acid bacteria probiotic cultures', Engineering in Life Sciences, 12(4), pp. 391-398. doi: 10.1002/elsc.201100118.

[8] Halim, M. et al. (2017) 'Effect of encapsulant and cryoprotectant on the viability of probiotic Pediococcus acidilactici ATCC 8042 during freeze-drying and exposure to high acidity, bile salts and heat', LWT - Food Science and Technology, 81, pp. 210-216. doi: 10.1016/j.lwt.2017.04.009.

[9] Hendrawan, Y., Sumarlan, S. H. and Ilham, N. A.-Z. (2017) 'Pengaruh Konsentrasi Ekstrak Cincau Hijau (Premna Oblongifolia L.) Sebagai Edible Coating dan Lama Pencelupan terhadap Kualitas Stroberi (Fragaria Sp.)', Jurnal Keteknikan Pertanian Tropis dan Biosistem, 5(1), pp. 35-48.

[10] Hill, C. et al. (2014) 'Expert consensus document: The international scientific association for probiotics and prebiotics consensus statement on the scope and appropriate use of the term probiotic', Nature Reviews Gastroenterology and Hepatology, 11(8), pp. 506-514. doi: 10.1038/nrgastro.2014.66.

[11] Iaconelli, C. et al. (2015) 'Drying process strongly affects probiotics viability and functionalities', Journal of Biotechnology, 214, pp. 17-26. doi: 10.1016/j.jbiotec.2015.08.022.

[12] Indriyani, A., Juffrie, M. and Setyati, A. (2012) 'Effect of Live versus Heat-Killed Probiotics Diarrhea in Young Children', 52(5), pp. 249-254. doi: 10.14238/pi. 
[13] Laličić-Petronijević, J. et al. (2017) 'Synergistic effect of three encapsulated strains of probiotic bacteria on quality parameters of chocolates with different composition', Journal of Functional Foods, 38, pp. 329-337. doi: 10.1016/j.jff.2017.09.041.

[14] Lapsiri, W., Bhandari, B. and Wanchaitanawong, P. (2013) 'Stability and Probiotic Properties of Lactobacillus plantarum Spray-Dried with Protein and Other Protectants', Drying Technology, 31(13-14), pp. 1723-1733. doi: 10.1080/07373937.2013.775658.

[15] Lin, L. et al. (2021) 'The effects of casein and whey proteins on the rheological properties of calcium-induced skim milk gels', International Dairy Journal, 113. doi: 10.1016/j.idairyj.2020.104893.

[16] Maciel, G. M. et al. (2014) 'Microencapsulation of Lactobacillus acidophilus La-5 by spray-drying using sweet whey and skim milk as encapsulating materials', Journal of Dairy Science, 97(4), pp. 1991-1998. doi: 10.3168/jds.2013-7463.

[17] Masood, M. I. et al. (2011) 'Beneficial effects of lactic acid bacteria on human beings', Critical Reviews in Microbiology, 37(1), pp. 91-98. doi: 10.3109/1040841X.2010.536522.

[18] Meneguin, A. B. et al. (2017) Resistant starch/pectin free-standing films reinforced with nanocellulose intended for colonic methotrexate release, Carbohydrate Polymers. Elsevier Ltd. doi: 10.1016/j.carbpol.2016.10.062.

[19] Mirković, M. et al. (2018) 'The sensory quality and volatile profile of dark chocolate enriched with encapsulated probiotic lactobacillus plantarum bacteria', Sensors (Switzerland), 18(8). doi: 10.3390/s18082570.

[20] Nambiar, R. B., Sellamuthu, P. S. and Perumal, A. B. (2018) 'Development of milk chocolate supplemented with microencapsulated Lactobacillus plantarum HM47 and to determine the safety in a Swiss albino mice model', Food Control, 94, pp. 300-306. doi: 10.1016/j.foodcont.2018.07.024.

[21] Nocianitri, K. A., Sujaya, I. N. and Ramona, Y. (2019) 'Mikroenkapsulasi Probiotik Lactobacillus Rhamnosus Fbb81 Dan Viabilitasnya Selama Penyimpanan', 6(1), pp. 7682.

[22] Poddar, D. et al. (2014) 'Stability of probiotic Lactobacillus paracasei during storage as affected by the drying method', International Dairy Journal, 39(1), pp. 1-7. doi: 10.1016/j.idairyj.2014.04.007.

[23] Pradipta, M. S. I. (2017) 'Pengaruh Mikroenkapsulasi Probiotik Bakteri Asam Laktat Indigenous Unggas Menggunakan Bahan Penyalut Maltodekstrin Terhadap Viabilitas Selama Penyimpanan', Journal of Livestock Science and Production, 1(1), pp. 37-43. doi: 10.31002/jalspro.v1i1.452.

[24] Reyes, V. et al. (2018) 'Influence of wall material on production of spray dried lactobacillus plantarum nrrl b-4496 and its viability at different storage conditions', Drying Technology, 36(14), pp. 1738-1748. doi: 10.1080/07373937.2017.1423324.

[25] Sanchez, V. et al. (2013) 'Freeze-Drying Encapsulation of Red Wine Polyphenols in an Amorphous Matrix of Maltodextrin', Food and Bioprocess Technology, 6(5), pp. 1350 1354. doi: 10.1007/s11947-011-0654-z.

[26] Sarao, L. K. and Arora, M. (2017) 'Probiotics, prebiotics, and microencapsulation: A review', Critical Reviews in Food Science and Nutrition, 57(2), pp. 344-371. doi: 10.1080/10408398.2014.887055.

[27] Sohail, A. et al. (2013) 'The Viability of Lactobacillus rhamnosus GG and Lactobacillus acidophilus NCFM Following Double Encapsulation in Alginate and Maltodextrin', Food and Bioprocess Technology, 6(10), pp. 2763-2769. doi: 10.1007/s11947-012-0938-y.

[28] Solanki, H. K. et al. (2013) 'Development of microencapsulation delivery system for longterm preservation of probiotics as biotherapeutics agent', BioMed Research International, 2013. doi: 10.1155/2013/620719.

[29] Soukoulis, C. et al. (2014) 'Impact of Milk Protein Type on the Viability and Storage Stability of Microencapsulated Lactobacillus acidophilus NCIMB 701748 Using Spray 
Drying', Food and Bioprocess Technology, 7(5), pp. 1255-1268. doi: 10.1007/s11947-0131120-x.

[30] Tang, H. W. et al. (2020) 'Influence of freeze-drying and spray-drying preservation methods on survivability rate of different types of protectants encapsulated Lactobacillus acidophilus FTDC 3081', Bioscience, Biotechnology and Biochemistry, 84(9), pp. 19131920. doi: 10.1080/09168451.2020.1770572.

[31] Todorov, S. D. and de Melo Franco, B. D. G. (2010) 'Lactobacillus plantarum: Characterization of the species and application in food production', Food Reviews International, 26(3), pp. 205-229. doi: 10.1080/87559129.2010.484113.

[32] Tripathi, M. K. and Giri, S. K. (2014) 'Probiotic functional foods: Survival of probiotics during processing and storage', Journal of Functional Foods, 9(1), pp. 225-241. doi: 10.1016/j.jff.2014.04.030.

[33] de Vos, P. et al. (2010) 'Encapsulation for preservation of functionality and targeted delivery of bioactive food components', International Dairy Journal, 20(4), pp. 292-302. doi: 10.1016/j.idairyj.2009.11.008.

[34] Wang, C. et al. (2019) 'Effects of polymerized whey protein on survivability of Lactobacillus acidophilus LA-5 during freeze-drying', Food Science and Nutrition, 7(8), pp. 2708-2715. doi: 10.1002/fsn3.1130.

[35] Wang, L. et al. (2016) 'Effect of skim milk coated inulin-alginate encapsulation beads on viability and gene expression of Lactobacillus plantarum during freeze-drying', LWT Food Science and Technology, 68, pp. 8-13. doi: 10.1016/j.lwt.2015.12.001.

[36] Winarsih, S. (2018) 'Pengawetan Strawberry (Fragaria Ananassa) Menggunakan Edible Coating Berbasis Pektin Dari Cincau Hijau (Cylea barbata)', Agrika, 12(2). doi: 10.31328/ja.v12i2.762.

[37] Wong, C. B., Odamaki, T. and Xiao, J. zhong (2019) 'Beneficial effects of Bifidobacterium longum subsp. longum BB536 on human health: Modulation of gut microbiome as the principal action', Journal of Functional Foods, 54(February), pp. 506-519. doi: 10.1016/j.jff.2019.02.002.

[38] Yan, T. and Goldman, R. D. (2020) 'Probiotics for antibiotic-associated diarrhea in children', Canadian Family Physician, 66(1), pp. 37-39.

[39] Yasmin, I. et al. (2019) 'Development of Whey Protein Concentrate-Pectin-Alginate Based Delivery System to Improve Survival of B. longum BL-05 in Simulated Gastrointestinal Conditions', Probiotics and Antimicrobial Proteins, 11(2), pp. 413-426. doi: 10.1007/s12602-018-9407-x. 